\title{
HUBUNGAN KONSUMSI FE DENGAN PANJANG BADAN PADA ANAK USIA 12-24 BULAN
}

\section{THE CORRELATION OF FE CONSUMPTION WITH CHILDREN'S HEIGHT AGED 12-24 MONTHS}

\author{
Eline Charla Sabatina Bingan \\ Jurusan Kebidanan Poltekkes Kemenkes Palangka Raya, Indonesia. \\ E-mail: elinecarlabingan@gmail.com
}

\begin{abstract}
ABSTRAK
Stunting (tubuh pendek) merupakan masalah kesehatan masyarakat yang harus ditangani secara serius. Hasil pemantauan Status Gizi (PSG) pada tahun 2016, sebesar 29\% balita Indonesia mengalami tubuh pendek. Faktor keturunan hanya berkontribusi sebesar $15 \%$, sementara unsur terbesar adalah terkait masalah asupan gizi, hormon pertumbuhan dan terjadinya penyakit infeksi berulang. Salah satu asupan gizi yang perlu diperhatikan ibu hamil adalah zat besi (Fe). Tujuan penelitian untuk mengetahui hubungan konsumsi $\mathrm{Fe}$ dengan panjang badan pada anak usia 12-24 bulan. Metode penelitian observasional analitik yaitu untuk mengetahui hubungan variabel bebas terhadap variabel terikat. Desain penelitian menggunakan Case Contol. Hasil analisis statistik bivariat menggunakan chi square menunjukkan bahwa ada hubungan panjang badan anak pada ibu yang patuh dan tidak patuh konsumsi Tablet Fe dengan nilai $P$ Value $0,002(\alpha<0,05)$. Ibu yang patuh mengonsumsi Tablet Fe memiliki risiko lebih kecil untuk terjadinya anak pendek (stunting) jika dibandingkan dengan ibu yang tidak patuh mengonsumsi Tablet Fe.
\end{abstract}

Kata Kunci : Balita pendek, Panjang badan, dan Zat Besi (Fe)

\begin{abstract}
Stunting (short body) is a public health problem that must be taken seriously. The results of monitoring the Nutrition Status (PSG) in 2016, amounting to $29 \%$ of Indonesian children under five experienced a short body. Heredity factors only contribute $15 \%$, while the biggest element is related to nutrition, growth hormone and recurrent infectious diseases. One nutrient intake that needs to be considered by pregnant women is iron $(\mathrm{Fe})$. The purpose of this study was to determine the relationship of Fe consumption with body length in children aged 12-24 months. The analytic observational research method is to find out the relationship between the independent variable and the dependent variable. The study design uses Case Contol. The results of the bivariate statistical analysis using chi square showed that there was a relationship between the length of the child's body in obedient and non-compliant mothers consuming $\mathrm{Fe}$ tablets with a $P$ value of $0.002(\alpha<0.05)$. Mothers who are obedient to consume Fe tablets have a smaller risk for the occurrence of short children (stunting) when compared to mothers who are not compliant to consume Fe tablets.
\end{abstract}

Keywords: Body length, Iron (Fe), and Short Toddlers 


\section{PENDAHULUAN}

Stunting merupakan masalah kesehatan masyarakat yang harus ditangani secara serius. Hasil Pemantauan Status Gizi (PSG) Laporan Tahun 2017, pada tahun 2016 sebesar $29 \%$ balita Indonesia mengalami stunting, yaitu 18,9\% (pendek) dan 10,1\% (sangat pendek). ${ }^{1}$ Kalimantan Tengah merupakan salah satu provinsi yang memiliki prevalensi stunting tinggi, yaitu sebesar $34,1 \%{ }^{2}$ Dari 14 kabupaten di provinsi Kalimantan Tengah, salah satunya adalah kabupaten Gunung Mas dengan angka prevalensi stunting diatas rata-rata provinsi yaitu sebesar $34,5 \%{ }^{2}$.

Di Indonesia masyarakat sering menganggap tubuh pendek sebagai faktor keturunan. Persepsi yang salah di masyarakat membuat masalah ini tidak mudah diturunkan dan membutuhkan upaya besar dari pemerintah dan berbagai sektor terkait. Hasil studi membuktikan bahwa pengaruh faktor keturunan hanya berkontribusi sebesar $15 \%$, sementara unsur terbesar adalah terkait masalah asupan zat gizi, hormon pertumbuhan dan terjadinya penyakit infeksi berulang. ${ }^{3}$

Status gizi dibagi menjadi dua yakni status gizi antropometri dan status gizi besi. Subjek dengan status gizi yang baik cenderung memiliki status kesehatan yang baik, fungsi dalam tubuh normal sehingga produksi hemoglobin juga akan lebih meningkat saat konsumsi $\mathrm{Fe}$ juga meningkat. ${ }^{4}$ lbu dengan gizi kurang sejak trimester awal akan melahirkan bayi dengan berat badan lahir rendah (BBLR) yang kemudian akan tumbuh menjadi balita stunting. ${ }^{5}$ Bayi prematur dengan berat lahir rendah, berat dan panjang badannya selain dipengaruhi oleh status gizi ibu, juga dipengaruhi oleh usia kehamilan. ${ }^{6}$ Penelitian di Brazil dengan design kohort membuktikan bahwa kelompok bayi lahir prematur memiliki risiko stunting saat usia 12 bulan sebesar 2,35 kali dan saat usia 24 bulan sebesar 2,30 kali. Bayi yang lahir normal juga dapat berisiko stunting jika asupan gizinya kurang seperti kualitas dan kualitas MP-ASI yang kurang karena MP-ASI yang baik mengandung sumber zat gizi makro dan mikro yang berperan dalam pertumbuhan linear.

Antisipasi awal balita stunting dapat dilakukan dengan melahirkan bayi dengan berat badan normal atau tidak BBLR. Salah satu faktor penyebab terjadinya BBLR yaitu ibu yang anemia. Penyebab utama terjadinya anemia pada ibu hamil adalah akibat kekurangan zat besi. Salah satu usaha pemerintah untuk mencegah anemia pada ibu hamil yaitu melalui program pemberian tablet besi (Fe).

Kementerian Kesehatan menganjurkan agar ibu hamil mengkonsumsi paling sedikit 90 tablet besi selama kehamilan. Namun tingkat kepatuhan ibu hamil mengkonsumsi tablet $\mathrm{Fe}$ masih rendah. Kepatuhan mengkonsumsi tablet Fe diukur dari ketepatan jumlah tablet yang dikonsumsi, ketepatan cara mengkonsumsi tablet besi, frekuensi konsumsi per hari. ${ }^{7}$ Oleh karena itu, tingginya angka kejadian stunting pada balita di Kalimantan Tengah khususnya di kabupaten Gunung Mas perlu mendapat perhatian khusus, sebab kejadian stunting bisa saja terus meningkat apabila faktor-faktor risiko yang telah dijelaskan sebelumnya tidak diperhatikan.

\section{METODE}

Penelitian ini merupakan jenis penelitian Observasional Analitik dengan pendekatan Kuantitatif dan desain penelitian Case Control. ${ }^{8}$ Penelitian ini dilakukan di Puskesmas Tampang Tumbang Anjir Kabupaten Gunung Mas Provinsi Kalimantan Tengah pada bulan Oktober 2018. Populasi dalam penelitian ini adalah anak tubuh 
pendek usia 12-24 bulan di Kabupaten Gunung Mas Provinsi Kalimantan Tengah tahun 2018 dengan sampel berjumlah 44 responden.

Teknik pengambilan data primer yang diperoleh melalui wawancara menggunakan Format Isian kepada ibu balita Panjang badan diperoleh melalui melakukan pengukuran tinggi badan dengan menggunakan Crown-heel leight/ length board/ Infantometer dengan tingkat ketelitian $0,1 \mathrm{~cm}$. Analisis univariat dalam penelitian ini akan disajikan dalam tabel distribusi frekuensi (persentase) yaitu untuk data kategorik seperti konsumsi Fe, KEK dan ASI eksklusif. Analisis bivariat yang dilakukan menggunakan chi square.

\section{HASIL}

\section{Analisis Univariat}

Tabel 1. Distribusi Usia Ibu

\begin{tabular}{cccc}
\hline Variabel & Mean & $\begin{array}{c}\text { Minimum- } \\
\text { Maximum }\end{array}$ & $\begin{array}{c}\text { Standar } \\
\text { Deviasi }\end{array}$ \\
\hline Usia & $\begin{array}{c}18,27 \\
\text { tahun }\end{array}$ & $13-24$ & 2,8 \\
& & \\
\hline
\end{tabular}

Berdasarkan tabel 1 rata rata usia ibu 18,27 tahun dengan usia termuda 13 tahun dan tertua 24 tahun. Standar deviasi usia ibu 2,8.

Tabel 2. Distribusi Frekuensi KEK, Asi Eksklusif dan Konsumen Tablet $\mathrm{Fe}$

\begin{tabular}{lcc}
\hline \multicolumn{1}{c}{ Variabel } & $\mathbf{n}$ & $\%$ \\
\hline Status KEK & & \\
\hline \multicolumn{1}{c}{ KEK } & 4 & $9,1 \%$ \\
\hline Tidak KEK & 40 & $90,9 \%$ \\
\hline ASI Eksklusif & & \\
\hline Ya & 33 & $75 \%$ \\
\hline$\quad$ Tidak & 11 & $25 \%$ \\
\hline $\begin{array}{l}\text { Konsumsi Tablet } \\
\text { Fe }\end{array}$ & & \\
\hline$\quad$ Patuh & 5 & $11,4 \%$ \\
\hline \multicolumn{1}{l}{ Tidak Patuh } & 39 & $88,6 \%$ \\
\hline
\end{tabular}

Berdasarkan tabel 2 Status KEK sebanyak $90,9 \%$ ibu tidak mengalami KEK, $75 \%$ ibu memberikan ASI Eksklusif dan 88,6\% tidak patuh dalam mengkonsumsi tablet $\mathrm{Fe}$.

Tabel 3. Distribusi Panjang Lahir, Berat Lahir dan Panjang Badan Saat Penelitian pada Anak

\begin{tabular}{lccl}
\hline Variabel & Mean & $\begin{array}{r}\text { Min- } \\
\text { Max }\end{array}$ & $\begin{array}{l}\text { Standar } \\
\text { Deviasi }\end{array}$ \\
\hline $\begin{array}{l}\text { Panjang } \\
\text { Lahir }\end{array}$ & $\begin{array}{c}48,52 \\
\mathrm{~cm}\end{array}$ & $43-53$ & 2,107 \\
\hline $\begin{array}{l}\text { Berat } \\
\text { Lahir }\end{array}$ & $\begin{array}{c}2944,11 \\
\text { gram }\end{array}$ & $\begin{array}{c}1200 \\
4800\end{array}$ & 627,53 \\
\hline $\begin{array}{l}\text { Panjang } \\
\text { Badan }\end{array}$ & 76,106 & $71,5-$ & \\
$\begin{array}{l}\text { saat } \\
\text { penelitian }\end{array}$ & $\mathrm{cm}$ & 84,3 & 3,53 \\
\hline
\end{tabular}

Berdasarkan tabel 3 panjang lahir anak menunjukkan hasil rata rata panjang lahir $48,52 \mathrm{~cm}$ dengan panjang terendah $43 \mathrm{~cm}$ dan panjang tertinggi $53 \mathrm{~cm}$, standar deviasi panjang lahiranak 2,107. Rata rata berat lahir anak 2944,11 gram dengan berat terendah 1200 gram dan berat tertinggi 4800 gram, standar deviasi 627,53 . Rata rata $76,106 \mathrm{~cm}$ dengan panjang terendah $71,5 \mathrm{~cm}$ dan panjang tertinggi $84,3 \mathrm{~cm}$, standar deviasi 3,53 .

Tabel 4. Distribusi Frekuensi Jenis Kelamin Anak

\begin{tabular}{lll}
\hline \multicolumn{1}{c}{ Variabel } & $\mathbf{n}$ & $\%$ \\
\hline Jenis Kelamin & & \\
\hline Laki-laki & 22 & $50 \%$ \\
\hline Perempuan & 22 & $50 \%$ \\
\hline
\end{tabular}

Berdasarkan tabel 4 sebanyak $50 \%$ anak berjenis kelamin laki-laki dan $50 \%$ anak berjenis kelamin perempuan. 


\section{Analisis Bivariat}

\begin{tabular}{|c|c|c|c|c|}
\hline \multirow{3}{*}{$\begin{array}{c}\text { Tabel } 5 \\
\\
\text { Kon- } \\
\text { sumsi } \\
\text { Fe } \\
\end{array}$} & \multicolumn{4}{|c|}{$\begin{array}{l}\text { Badan antara Patuh dan Tidak } \\
\text { Patuh Konsumsi Fe }\end{array}$} \\
\hline & \multicolumn{2}{|c|}{ Panjang Badan } & \multirow[b]{2}{*}{ Total } & \multirow{2}{*}{$\begin{array}{c}P \\
\text { value }\end{array}$} \\
\hline & Stunting & $\begin{array}{c}\text { Tidak } \\
\text { Stunting }\end{array}$ & & \\
\hline Patuh & $\begin{array}{c}3 \\
(18,8 \%)\end{array}$ & $\begin{array}{c}13 \\
(81,2 \%)\end{array}$ & $\begin{array}{c}16 \\
(36,4 \%)\end{array}$ & \\
\hline \multirow[t]{2}{*}{$\begin{array}{l}\text { Tidak } \\
\text { Patuh }\end{array}$} & $\begin{array}{c}19 \\
(67,9 \%)\end{array}$ & $\begin{array}{c}9 \\
(32,1 \%)\end{array}$ & $\begin{array}{c}28 \\
(63,6 \%)\end{array}$ & 0,002 \\
\hline & 22 & 22 & $\begin{array}{c}44 \\
(100 \%) \\
\end{array}$ & \\
\hline
\end{tabular}

Jumlah responden dengan panjang badan anak Stunting pada kelompok ibu yang patuh konsumsi $\mathrm{Fe}$ yaitu 3 orang $(18,8 \%)$ dan panjang badan tidak Stunting pada kelompok ibu yang patuh Konsumsi Fe yaitu 13 orang $(81,2 \%)$, sedangkan jumlah responden dengan panjang badan anak Stunting pada kelompok ibu yang tidak patuh konsumsi Fe yaitu 19 orang $(67,9 \%)$, serta jumlah responden dengan panjang badan anak tidak stunting berjumlah 9 orang $(32,1 \%)$. Hasil analisa statistik menunjukkan bahwa ada hubungan panjang badan anak pada ibu yang patuh dan tidak patuh konsumsi $\mathrm{Fe}$ sebesar nilai $P$ Value $0,002(\alpha<0,05)$.

\section{PEMBAHASAN}

Berdasarkan hasil penelitian konsumsi Tablet Fe dari 44 ibu nifas yang menyatakan patuh mengkonsumsi Tablet $\mathrm{Fe}$ sebanyak 16 responden $(36,4 \%)$ dan yang tidak patuh mengkonsumsi Tablet $\mathrm{Fe} 28$ responden $(63,6 \%)$. Dengan hasil analisis sebesar $P$ Value $0,002(\alpha<0,05)$. Penelitian lain oleh Wiwien Fitrie Wellina, dll, menunjukkan bahwa faktor risiko terjadinya anak pendek (stunting) adalah kurangnya asupan energi, protein, dan seng. ${ }^{10}$ Bayi dua tahun yang tingkat kecukupan sengnya rendah memiliki peluang anak pendek sebesar $8,78 \%$ kali dibandingkan dengan baduta yang tingkat kecukupan sengnya baik.

Sejalan dengan hasil penelitian bahwa anak yang bertubuh pendek dapat mempengaruhi tumbuh kembang anak sebagai masa depan yang baik. ${ }^{10}$ Zat besi sangat dibutuhkan oleh ibu hamil untuk mencegah terjadinya anemia dan menjaga pertumbuhan janin secara optimal. Kementerian Kesehatan menganjurkan agar ibu hamil mengonsumsi paling sedikit 90 pil zat besi selama kehamilannya. ${ }^{11}$

Suplementasi zat besi harian direkomendasikan sebagai intervensi kesehatan masyarakat dalam menstruasi wanita dewasa dan remaja putri, yang hidup di rangkaian di mana anemia sangat prevalen ( $\geq 40 \%$ prevalensi anemia), untuk pencegahan anemia dan defisiensi zat besi (rekomendasi kuat, kualitas moderat). ${ }^{12}$

Pengukuran panjang badan digunakan untuk menilai status perbaikan gizi. Selain itu, panjang badan merupakan indikator yang baik untuk pertumbuhan fisik yang sudah lewat (stunting) dan untuk perbandingan terhadap perubahan relatif, seperti nilai berat badan dan lingkar lengan atas. ${ }^{13}$ Panjang badan merupakan indikator untuk mengetahui gangguan pertumbuhan fisik yang telah lewat (stunting). Panjang badan juga salah satu prediktor kualitas sumber daya manusia. Panjang badan yang pendek menunjukkan bahwa kualitas sumber daya manusia dalam keadaan buruk dan selanjutnya akan menurunkan kemampuan produktivitas bangsa di masa depan.

Kekurangan zat besi selama kehamilan sangat umum terjadi. Diperkirakan setengah dari semua wanita hamil di seluruh dunia kekurangan zat besi. ${ }^{14}$ Jika tidak mendapatkan cukup zat besi dari makanan, tubuh secara bertahap mengambilnya dari penyimpanan zat besi di tubuh sehingga berisiko meningkatkan anemia. Menurut para ahli, anemia yang diakibatkan oleh kekurangan zat besi di dua trimester pertama dikaitkan dengan risiko dua kali lipat bayi lahir prematur dan tiga kali lipat risiko berat badan lahir rendah. Stunting mulai terjadi ketika janin masih dalam kandungan disebabkan oleh asupan makanan ibu selama kehamilan yang kurang bergizi. ${ }^{15}$ 
Akibatnya, gizi yang didapat anak dalam kandungan tidak mencukupi. Kekurangan gizi akan menghambat pertumbuhan bayi dan bisa terus berlanjut setelah kelahiran.

\section{SIMPULAN DAN SARAN}

Penelitian ini menunjukkan bahwa ibu yang patuh mengonsumsi Tablet Fe memiliki risiko lebih kecil untuk terjadinya anak pendek (stunting) jika dibandingkan dengan ibu yang tidak patuh mengonsumsi Tablet $\mathrm{Fe}$ yang akan memiliki risiko lebih besar untuk terjadinya stunting. Kekurangan zat besi ( $\mathrm{Fe})$ selama kehamila akan meningkatkan terjadinya anemia. Anemia menyebabkan risiko bayi lahir premature dan berat badan lahir rendah. Bayi yang lahir dengan BBLR dan premature akan memiliki risiko stunting saat usia 12 bulan sebesar 2,35 kali dan saat usia 24 bulan sebesar 2,30 kali.

Saran bagi tenaga kesehatan terutama bidan agar terus meningkatkan kepatuhan ibu hamil dalam mengkonsumsi Tablet Fe untuk mengurangi angka kejadian stunting pada balita di Kalimantan Tengah khususnya di kabupaten Gunung mas yang perlu mendapatkan perhatian khusus.

\section{UCAPAN TERIMAKASIH}

Peneliti berterima kasih kepada Puskesmas Tampang Tumbang Anjir Kabupaten Gunung Mas Provinsi Kalimantan Tengah yang sudah memfasilitasi peneliti selama proses penelitian ini berlangsung.

\section{DAFTAR PUSTAKA}

1. Kemenkes RI. Pusat Data dan Informasi: Situasi Balita Pendek. 2016.

2. Kemenkes RI. Buku Saku Hasil Pemantauan Status Gizi (PSG) dan Penjelasannya Tahun 2017. Direktorat Gizi Masyarakat Direkteroat Dikjen Kesmas Kementerian Kesehatan. 2017.

3. Nurhayati, dkk. Pengaruh Asupan Tablet Zat Besi (Fe) Terhadap Kadar
Haemoglobin $(\mathrm{Hb})$ Pada lbu Hamil Di Puskesmas Kopelma Darussalam Tahun 2014. Idea Nursing Journal. 2015;6(3):7682.

4. Sari M, Pee Sd, et al. Higher Household Expenditure on animal-source and nongrain foods lowers the risk of stunting among children 0-59 months old in indonesia: implications of rising food prices. The journal of nutrition. 2010; 140:196-200.

5. Santos IS, Matijasevich A, et al. Late Preterm Birth is Risk Factor For Growth Faltering in Early Childhood: a cohort study. BMC Pediatr. 2009; 9: 71-80.

6. Fitrie Wellina, Wiwien dkk., Faktor risiko stunting pada anak umur 12-24 bulan. Jurnal Gizi Indonesia.2016;5(1): 55-61.

7. Irna Mantika, Anggidan Mulyati, Tatik. Hubungan Asupan Energi, Protein, Zat Besi dan Aktivitas Fisik dengan Kadar Hemoglobin Tenaga Kerja Wanita di Pabrik Pengolahan Rambut Pt. Won Jin Indonesia. JNC (Journal of Nutrition College). n College. 2014;3(4):848-854

8. Thompson, John et al. Effects of Daily Iron Supplementation in 2- to 5-Year Old Children: Systematic Review and Metaanalysis. PROSPERO International Prospective Register of Systematic Reviews. 2012.

9. Dharma, Kelana Kusuma. Metodologi Penelitian Keperawatan. Jakarta : CV. Trans Info Media; 2011.

10.Permatasari Tyas, dkk. Efektivitas Program Suplementasi Zat Besi pada Remaja Putri di Kota Bogor. JURNAL MKMI.2018;14(1).

11.Tim Nasional Percepatan Penanggulangan Kemiskinan. 100 Kabupaten/Kota Prioritas Untuk Intervensi Anak Kerdil (Stunting): Ringkasan. 2017.

12.WHO. Daily Iron Supplementation: In Adult Women And Adolescent Girls. WHO Library Cataloguing;2016

13.Umbreen Faiza,dkk. Effects of Iron Supplementation on the Height of the Zones of Growth Cartilage of Rat. JIIMC. 2017;12(3) 


\section{Media Informasi}

14.Kementerian Kesehatan Republik Indonesia. Angka Kecukupan Gizi yang dianjurkan bagi bangsa Indonesia. 2013

15.Susanti, Dyah. Tingkat Kepatuhan Ibu Multigravida Mengonsumsi Tablet Fe di
Puskesmas Polanharjo Klaten. Surakarta: Sekolah Tinggi IImu Kesehatan Kusuma Husada.Surakarta; 